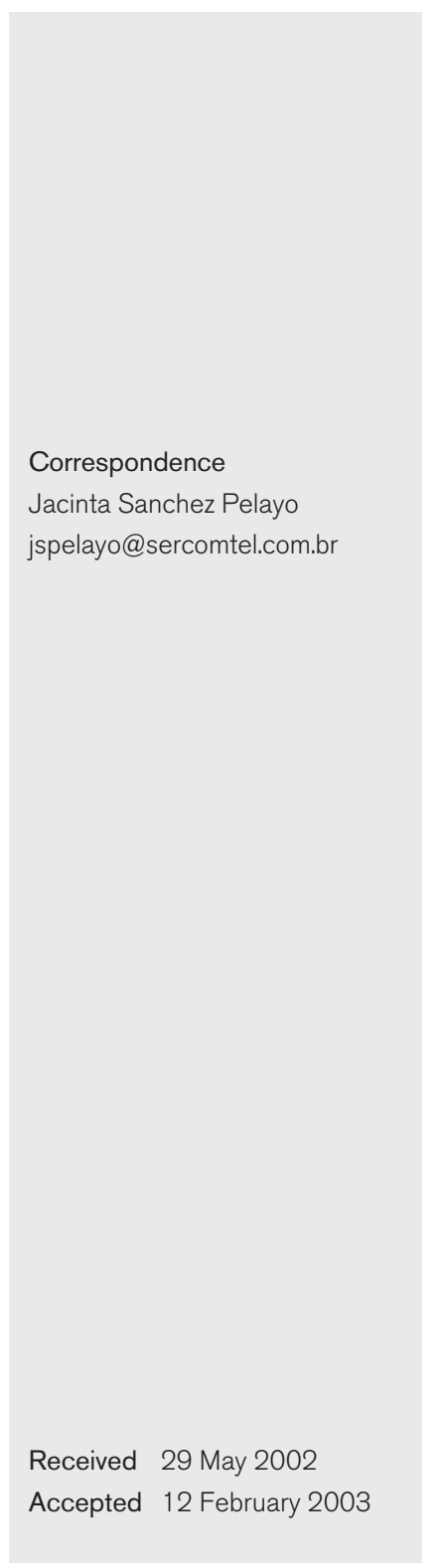

\title{
Genotypic and phenotypic characterization of attaching and effacing Escherichia coli (AEEC) isolated from children with and without diarrhoea in Londrina, Brazil
}

\author{
Eliane Blanco Nunes, ${ }^{1}$ Halha Ostrensky Saridakis, ${ }^{1}$ Kinue $\mid r i n o{ }^{2}$ and \\ Jacinta Sanchez Pelayo ${ }^{1}$ \\ ${ }^{1}$ Departamento de Microbiologia, Universidade Estadual de Londrina, Londrina, PR, Brazil \\ ${ }^{2}$ Instituto Adolfo Lutz, São Paulo, SP, Brazil
}

\begin{abstract}
Attaching and effacing Escherichia coli (AEEC) have been implicated in diarrhoea in humans in several countries. A total of $919 \mathrm{E}$. coli strains, isolated from 125 children with diarrhoea and 98 without diarrhoea, was investigated by PCR for the presence of the EAF, bfp, eae and stx genes. Thirty-four of these isolates were found to carry the eae gene; they were isolated from 27 $(79.4 \%)$ children with diarrhoea and seven (20.6\%) controls, in the city of Londrina, Brazil. These strains were investigated for their genotypic and phenotypic characteristics. Different genetic profiles were observed; strains containing the eae gene alone were most common (47.1\%). The characteristic genetic profile of typical enteropathogenic E. coli (EPEC), eae, bfp and EAF, was only found in isolates from children with diarrhoea. The stx gene was not detected in any of the 34 strains studied. Ten $(29.4 \%)$ strains were negative in the fluorescent actin-staining test. Localized adhesion (LA) was the most common pattern of adhesion (44.1\%), followed by the aggregative adhesion (AA) (23.5\%) and localized adhesion-like (LAL) (14.7\%) patterns. The results showed a strong association between strains presenting the LA pattern and diarrhoea. Forty-seven per cent of the strains studied belonged to classical O-serogroups of EPEC. The most common serotype found was O119:H6; these isolates all showed the LA pattern, were positive for fluorescent actin-staining and were associated with diarrhoea. Intimin $\beta$ was detected in seven strains, four of which belonged to serotype O119: $\mathrm{H} 6$ and three to serotype ONT : $\mathrm{H} 7$; all were associated with diarrhoea. On the other hand, intimin $\varepsilon$ was detected in two strains of serotype O111: H38 and one of serotype ONT:H19, isolated from children without diarrhoea. To our knowledge, this is the first report of the occurrence of intimin $\varepsilon$ in strains of $E$. coli isolated from humans in Brazil.
\end{abstract}

\section{INTRODUCTION}

Attaching and effacing Escherichia coli (AEEC) are characterized by their ability to cause intestinal lesions, known as attaching and effacing (AE) lesions. These are characterized by intimate attachment of the bacterium to the host cell, the effacement of enterocyte microvilli and formation of pedestal-like structures (Knutton et al., 1989).

The genes necessary for $\mathrm{AE}$ lesion formation are located on

Abbreviations: AA, aggregative adhesion; AEEC, attaching and effacing E. coli; DA, diffuse adhesion; EAF, EPEC adherence factor; EHEC, enterohaemorrhagic E. coli; EPEC, enteropathogenic E. coli; FAS, fluorescent actin-staining; IS, isolated bacteria; LA, localized adhesion; LAL, localized adhesion-like; LEE, locus of enterocyte effacement; NA, non-adherent. the bacterial chromosome, forming a pathogenicity island called the locus of enterocyte effacement (LEE) (McDaniel et al., 1995). The LEE contains genes encoding a type-III secretion system (sep and esc), a number of secreted proteins [EspA, EspD, EspB and Tir (translocated intimin receptor)] and intimin (eae), a $94 \mathrm{kDa}$ outer-membrane protein that mediates the intimate adhesion between the bacterium and the epithelial cell membrane (Kenny et al., 1997; Nataro \& Kaper, 1998). The AE lesion can be observed by the fluorescent actin-staining (FAS) test; it gives rise to intense fluorescence of filamentous actin, which can be observed in the host cell beneath the site of bacterial attachment (Knutton et al., 1989).

Enteropathogenic (EPEC) and enterohaemorrhagic (EHEC) E. coli are often grouped together as AEEC. In addition to 
their ability to induce AE lesions, EPEC possess the large EPEC adherence factor (EAF) plasmid and the cluster of genes that encodes bundle-forming pili (BFP) (Baldini et al., 1983; Girón et al., 1991). EPEC are a common cause of severe infantile diarrhoea, particularly in developing countries (Nataro \& Kaper, 1998). These strains are characterized by a pattern of adhesion to epithelial cells called localized adhesion (LA), and are found among 12 different Oserogroups (O26, O55, O86, O111, O114, O119, O125O128, O142 and O158) (Scaletsky et al., 1984).

EPEC strains carrying the eae gene, but lacking the EAF plasmid and stx (Shiga toxin) genes, were described as atypical EPEC (Kaper, 1996) at the Second International Symposium on EPEC (São Paulo, Brazil, 1995). Atypical EPEC strains were found in several EPEC O-serogroups, but belonged to serotypes different from those of typical EPEC (Pelayo et al., 1999). These strains present an adhesion pattern called localized adhesion-like (LAL), characterized by the presence of less compact microcolonies or clusters of bacteria in a few cells (Scaletsky et al., 1996, 1999).

EHEC are typically characterized by the ability to cause the $\mathrm{AE}$ lesion, possession of a $60 \mathrm{MDa}$ plasmid encoding enterohaemolysin and production of the Shiga toxins (Stx1 and/or Stx2), which are responsible for the major symptoms of haemorrhagic colitis (HC) and haemolytic uraemic syndrome (HUS) (Nataro \& Kaper, 1998). Serotype O157:H7 is more frequently associated with disease in humans and animals, but other serotypes, such as $\mathrm{O} 26: \mathrm{H} 11, \mathrm{O} 111: \mathrm{H}^{-}, \mathrm{O} 111: \mathrm{H} 8, \mathrm{O} 103: \mathrm{H} 2, \mathrm{O} 118: \mathrm{H}^{-}$ and O118: H16, have also been implicated (Nataro \& Kaper, 1998). In a recent study performed in São Paulo, Brazil, Vieira et al. (2001) identified E. coli associated with infantile diarrhoea that belonged to non-EPEC serogroups, carried the eae gene and lacked the EAF and stx probe sequences.

The eae gene has been cloned and sequenced from several EPEC and EHEC strains isolated from humans and animals, RDEC (a rabbit EPEC-like E. coli strain), Citrobacter freundii and Hafnia alvei (Jerse et al., 1990; Beebakhee et al., 1992; Frankel et al., 1994; Agin \& Wolf, 1997). These genes possess a highly conserved $\mathrm{N}$-terminal region, whereas the C-terminal region shows much less similarity (Frankel et al., 1994). Frankel et al. (1995) have demonstrated that the binding activity of intimin is located in the C-terminal region.

Adu-Bobie et al. (1998) used PCR and antiserum against the C-terminal region of intimin to investigate the antigenic variation in this region, and identified four distinct intimin types: intimins $\alpha, \beta, \gamma$ and $\delta$. More recently, Oswald et al. (2000) characterized a new intimin, referred to as intimin $\epsilon$, which was present in human and bovine EHEC strains.

The aim of this study was to determine the genotypic and phenotypic characteristics of AEEC isolated from children with and without diarrhoea in Londrina, Brazil. The investigation has been prompted by the lack of data concerning diarrhoea caused by these micro-organisms in children from this region, and by the need for better understanding of their enteropathogenic potential.

\section{METHODS}

Bacterial strains. A total of $919 \mathrm{E}$. coli isolates was examined in this study; 524 of these were selected from 125 children with symptoms of gastrointestinal disorders (patients) and 395 from 98 children without diarrhoea (controls). The population for analysis was selected from children attending the emergency room of public hospitals (patients), day-care centres and a clinical laboratory (controls) in Londrina, in the north of Paraná state, Brazil. Strains were isolated between February 1995 and May 1996, and between July 1998 and January 1999, on MacConkey agar plates (Biobrás, Brazil). From each faecal sample, five lactose-fermenting colonies and one non-lactose-fermenting colony were identified by biochemical tests (Edwards \& Ewing, 1972). E. coli strains were stored at $-70{ }^{\circ} \mathrm{C}$ in tryptic soy broth (Biobrás) with $15 \%$ $(\mathrm{v} / \mathrm{v})$ glycerol. Bacterial strains used as positive controls in this study are listed in Table 1. Strain HB101 (E. coli K-12) was used as the negative control in all tests.

PCR. All 919 E. coli isolates were screened for the presence of the genetic sequences of EAF, $b f p$, eae and $s t x$. Strains positive for eae by PCR were analysed further to identify the intimin type present. Table 2 shows the primer sequences, sizes of amplified DNA fragments and amplification conditions for all sequences studied. Amplification reactions were performed as follows: cultures on tryptic soy agar (Difco) were suspended in $300 \mu \mathrm{l}$ Milli-Q water (Millipore) and boiled for $10 \mathrm{~min}$ to release and denature the bacterial DNA. Amplification of bacterial DNA was carried out in volumes of $25 \mu \mathrm{l}$, containing $10 \mu \mathrm{l}$ bacterial lysate, $200 \mu \mathrm{M}$ dNTPs, $1.5 \mathrm{mM} \mathrm{MgCl}_{2}, 20$ pmol each primer and $1.5 \mathrm{U}$ Taq DNA polymerase (all Gibco-BRL). After amplification, products were electrophoresed in $1 \%$ agarose gel (Difco), stained with ethidium bromide (Gibco-BRL) and visualized using UV light.

HEp-2 cell adherence assay. The eae-positive strains were tested for adhesion to HEp-2 cells, as described by Cravioto et al. (1979). When the adhesion pattern was not defined after $3 \mathrm{~h}$ incubation, the test was repeated with a $6 \mathrm{~h}$ incubation period.

DNA hybridization. E. coli strains carrying eae and displaying an aggregative adhesion (AA) pattern were tested for hybridization with the specific DNA probe EAEC (enteroaggregative E. coli adherence

Table 1. Bacterial strains used as positive controls in this study

\begin{tabular}{|lll|}
\hline Strain & \multicolumn{1}{c|}{ Description } & \multicolumn{1}{c|}{ Reference } \\
\hline E2348/69 & Human EPEC O127: H6 & Jerse et al. $(1990)$ \\
EDL933 & Human EHEC O157: H7 & Yu \& Kaper (1992) \\
H19 & Human EHEC O26: H11 & Agin \& Wolf (1997) \\
PMK5 & Human EHEC O103: H2 & Oswald et al. (2000) \\
\hline
\end{tabular}


Table 2. Primer sequences, sizes of amplified DNA fragments and amplification conditions used in this study

\begin{tabular}{|c|c|c|c|c|c|c|c|}
\hline \multirow[t]{2}{*}{ Target } & \multicolumn{2}{|c|}{ Primer sequence $\left(5^{\prime} \rightarrow 3^{\prime}\right)$} & \multirow{2}{*}{$\begin{array}{c}\text { Amplified fragment } \\
\text { size }(b p)\end{array}$} & \multirow{2}{*}{$\begin{array}{c}\text { Amplification } \\
\text { conditions }\end{array}$} & \multirow[t]{2}{*}{ Cycles $(n)$} & \multirow{2}{*}{$\begin{array}{l}\text { Control } E \text {. coli } \\
\text { strains positive }\end{array}$} & \multirow[t]{2}{*}{ Reference } \\
\hline & Forward & Reverse & & & & & \\
\hline eae & TCGTCACAGTTGCAGGCCTGGT & CCGAAGTCTTATCAGCCGTAAAGT & 1100 & $\begin{array}{l}94^{\circ} \mathrm{C}(1 \mathrm{~min}) \\
60^{\circ} \mathrm{C}(1 \mathrm{~min}) \\
72{ }^{\circ} \mathrm{C}(1 \mathrm{~min})\end{array}$ & 30 & $\mathrm{E} 2348 / 69$ & Louie et al. (1993) \\
\hline EAF & CAGGGTAAAAGAAAGATGATAA & TATGGGGACCATGTATTATCA & 397 & $\begin{array}{l}94^{\circ} \mathrm{C}(1 \mathrm{~min}) \\
56{ }^{\circ} \mathrm{C}(2 \mathrm{~min}) \\
72^{\circ} \mathrm{C}(1 \mathrm{~min})\end{array}$ & 30 & E2348/69 & Franke et al. (1994) \\
\hline$b f p$ & CAATGGTGCTTGCGCTTGCT & GCCGCTTTATCCAACCTGGT & 326 & $\begin{array}{l}94{ }^{\circ} \mathrm{C}(1 \mathrm{~min}) \\
60{ }^{\circ} \mathrm{C}(1 \mathrm{~min}) \\
72{ }^{\circ} \mathrm{C}(1 \mathrm{~min})\end{array}$ & 30 & E2348/69 & $\begin{array}{l}\text { Gunzberg et al. } \\
\text { (1995) }\end{array}$ \\
\hline$s t x$ & CAACGAAATAATTTATATGT & TTTGATTGTTACAGTCAT & 887 & $\begin{array}{l}94^{\circ} \mathrm{C}(1 \mathrm{~min}) \\
45^{\circ} \mathrm{C}(90 \mathrm{~s}) \\
72{ }^{\circ} \mathrm{C}(90 \mathrm{~s})\end{array}$ & 39 & EDL933 & Lin et al. (1993) \\
\hline \multicolumn{8}{|c|}{ Intimin gene typing: } \\
\hline$\alpha$ & CCCGAATTCGGCACAAGCATAAGC & CCCGAATTCTTATTTTACACAAGTGGC & 2807 & $\begin{array}{l}94^{\circ} \mathrm{C}(45 \mathrm{~s}) \\
48^{\circ} \mathrm{C}(1 \mathrm{~min}) \\
72{ }^{\circ} \mathrm{C}(150 \mathrm{~s})\end{array}$ & 30 & E2348/69 & Oswald et al. (2000) \\
\hline$\beta$ & CCCGAATTCGGCACAAGCATAAGC & CCCGTGATACCAGTACCAATTACGGTC & 2287 & $\begin{array}{l}94^{\circ} \mathrm{C}(45 \mathrm{~s}) \\
59^{\circ} \mathrm{C}(1 \mathrm{~min}) \\
72{ }^{\circ} \mathrm{C}(150 \mathrm{~s})\end{array}$ & 30 & H19 & Oswald et al. (2000) \\
\hline$\gamma$ & CCCGAATTCGGCACAAGCATAAGC & CCCGAATTCTTATTCTACACAAACCGC & 2792 & $\begin{array}{l}94^{\circ} \mathrm{C}(45 \mathrm{~s}) \\
59^{\circ} \mathrm{C}(1 \mathrm{~min}) \\
72{ }^{\circ} \mathrm{C}(150 \mathrm{~s})\end{array}$ & 30 & EDL933 & Oswald et al. (2000) \\
\hline$\epsilon$ & CCCGAATTCGGCACAAGCATAAGC & AGCTCACTCGTAGATGACGGCAAGCG & 2608 & $\begin{array}{l}9{ }^{\circ} \mathrm{C}(45 \mathrm{~s}) \\
65^{\circ} \mathrm{C}(1 \mathrm{~min}) \\
72{ }^{\circ} \mathrm{C}(150 \mathrm{~s})\end{array}$ & 30 & PMK5 & Oswald et al. (2000) \\
\hline
\end{tabular}


plasmid), a 1 kb EcoRI-PstI fragment of pCVD432 (Baudry et al., 1990) labelled with $\left[\alpha-{ }^{32} \mathrm{P}\right] \mathrm{dATP}$, in a colony hybridization assay.

FAS test. The FAS test, which demonstrates the presence of filamentous actin beneath attached bacteria, was performed as described by Knutton et al. (1989). The strains were tested after 3 and 6 h incubation.

Haemolysin assay. All eae-positive strains were tested for production of haemolysin as described by Beutin (1991). The strains were cultivated on blood agar base (Difco), supplemented with $10 \mathrm{mM} \mathrm{CaCl}_{2}$ and $5 \%$ defibrinated sheep erythrocytes washed three times in PBS. Plates were examined for zones of haemolysis around bacterial growth after 3 and $24 \mathrm{~h}$ incubation at $37^{\circ} \mathrm{C}$.

Serotyping. Identification of somatic $(\mathrm{O})$ and flagellar $(\mathrm{H})$ antigens was performed in all eae-positive strains in the Enteric section of Instituto Adolfo Lutz, São Paulo, with specific antisera $\mathrm{O} 1-\mathrm{O} 173$ and $\mathrm{H} 1-\mathrm{H} 52$.

\section{RESULTS AND DISCUSSION}

AEEC are characterized by their ability to induce the AE lesion in the intestine; this process is mediated by an outermembrane protein encoded by the eae gene. This category of E. coli has been implicated in diarrhoea in humans and animals in several countries (Pelayo et al., 1999; Aidar et al., 2000; Vieira et al., 2001).

In this study, of 919 E. coli strains isolated from 125 children with diarrhoea and 98 without diarrhoea, 34 strains possessed the eae gene, either alone or associated with the other genes investigated. Twenty-seven of these strains $(79.4 \%)$ were isolated from cases of diarrhoea and seven (20.6\%) from controls. A summary of the genotypic and phenotypic characteristics of these strains is shown in Table 3.

Four different genetic profiles were found (Table 3). Strains

Table 3. Genotypic and phenotypic characteristics of $E$. coli strains possessing the eae gene

\begin{tabular}{|c|c|c|c|c|c|}
\hline Genetic profile & Type of adhesion & FAS reactivity & Intimin type & Serotype & Origin \\
\hline eae & LAL & + & NT & ONT: H11 & $\mathrm{P}$ \\
\hline eae & LAL & + & NT & ONT: H19 & $\mathrm{P}$ \\
\hline eae & LAL & + & NT & O86 : H8 & $\mathrm{P}$ \\
\hline eae & LAL & - & NT & O78: H49 & $\mathrm{P}$ \\
\hline eae & $\mathrm{AA}$ & + & NT & ONT : H19 & $\mathrm{P}$ \\
\hline eae & $\mathrm{AA}$ & - & NT & $\mathrm{O} 24: \mathrm{H} 40$ & $\mathrm{P}$ \\
\hline eae & AA & + & NT & $\mathrm{O} 26: \mathrm{H}^{-}$ & $\mathrm{P}$ \\
\hline eae & AA & - & NT & O111: H9 & $\mathrm{P}$ \\
\hline eae & $\mathrm{AA}$ & - & NT & O114:HNT & $\mathrm{P}$ \\
\hline eae & $\mathrm{DA}$ & - & NT & $\mathrm{O} 12: \mathrm{H}^{-}$ & $\mathrm{P}$ \\
\hline eae & NA & - & NT & $\mathrm{O} 1: \mathrm{H} 11$ & $\mathrm{P}$ \\
\hline eae & $\mathrm{AA}$ & + & $\epsilon$ & O111:H38 & C \\
\hline eae & LAL & + & $\epsilon$ & ONT: H19 & C \\
\hline eae & IS & + & $\epsilon$ & O111: H38 & C \\
\hline eae & IS & - & NT & $\mathrm{O} 127: \mathrm{H} 40$ & C \\
\hline eae & NA & - & NT & ONT: $\mathrm{H7}$ & C \\
\hline eae, EAF & $\mathrm{AA}$ & - & NT & ONT $: \mathrm{H}^{-}$ & $\mathrm{P}$ \\
\hline$e a e, \mathrm{EAF}$ & LA & + & NT & O142: H34 & C \\
\hline$e a e, b f p$ & LA & + & NT & $\mathrm{O} 107: \mathrm{H}^{-}$ & $\mathrm{P}$ \\
\hline$e a e, b f p$ & LA & + & NT & $\mathrm{O} 107: \mathrm{H}^{-}$ & $\mathrm{P}$ \\
\hline$e a e, b f p$ & LA & + & NT & O111:H6 & $\mathrm{P}$ \\
\hline$e a e, b f p$ & LA & + & NT & $\mathrm{O} 119: \mathrm{H} 2$ & $\mathrm{P}$ \\
\hline$e a e, b f p$ & LA & + & $\beta$ & O119: H6 & $\mathrm{P}$ \\
\hline$e a e, b f p$ & IS & - & NT & ONT: HNT & $\mathrm{P}$ \\
\hline$e a e, b f p$ & $\mathrm{AA}$ & + & NT & $\mathrm{O} 148: \mathrm{H} 28$ & C \\
\hline$e a e, b f p$, EAF & LA & + & $\beta$ & ONT : H7 & $\mathrm{P}$ \\
\hline$e a e, b f p$, EAF & LA & + & $\beta$ & ONT : H7 & $\mathrm{P}$ \\
\hline$e a e, b f p$, EAF & LA & + & $\beta$ & ONT : H7 & $\mathrm{P}$ \\
\hline$e a e, b f p$, EAF & LA & + & NT & ONT: $\mathrm{H7}$ & $\mathrm{P}$ \\
\hline$e a e, b f p$, EAF & LA & + & NT & O111:H6 & $\mathrm{P}$ \\
\hline$e a e, b f p$, EAF & LA & + & $\beta$ & O119: H6 & $\mathrm{P}$ \\
\hline$e a e, b f p, \mathrm{EAF}$ & LA & + & $\beta$ & O119:H6 & $\mathrm{P}$ \\
\hline$e a e, b f p$, EAF & LA & + & NT & O119: H6 & $\mathrm{P}$ \\
\hline$e a e, b f p$, EAF & LA & + & $\beta$ & O119:H6 & $\mathrm{P}$ \\
\hline
\end{tabular}

Abbreviations: NT, not typable; P, patient; C, control. 
possessing the eae gene alone $(47 \cdot 1 \%)$ were most frequent, and were found in children both with and without gastrointestinal disease. In contrast, the characteristic genetic profile of typical EPEC (eae, $b f p$ and EAF) was found only in children with diarrhoea.

The stx gene was not detected in any of the 34 strains identified as eae-positive. In Brazil, the incidence of EHEC in humans is very low in contrast with that of EPEC (Giraldi et al., 1990; Gomes et al., 1991; Saridakis, 1994). In fact, it is possible that EPEC infections in early childhood confer cross-reactive protective immunity against EHEC types that share common antigens (such as LPS and intimin) with classical EPEC strains (Beutin et al., 1998). This could explain why human infections with eae-positive EHEC occur less frequently in developing countries where infections of children by EPEC are common.

Five distinct adhesion patterns were observed (Table 3): LA, AA, LAL, DA (diffuse adhesion) and IS (isolated bacteria). Two strains were non-adherent (NA). LA was the most frequent pattern of adhesion (44.1\%), followed by AA (23.5\%), LAL ( $14.7 \%)$, IS ( $8.8 \%)$ and DA (2.9\%). Strains with AA, LAL and IS were found in children both with and without diarrhoea. The only strain that presented the DA pattern was isolated from a child without diarrhoea. All strains that presented the genetic profile of typical EPEC showed the LA pattern. Our results show a strong association between strains that presented the LA pattern and diarrhoea (one from the control group and 14 from patients). The strains that displayed the AA pattern did not hybridize with the EAEC probe.

Of all the eae-positive strains, 10 (29.4\%) were FAS-negative after incubation for 3 or $6 \mathrm{~h}$. The majority of the eae-positive, FAS-negative strains possessed the eae gene alone $(80 \%)$. Vieira et al. (2001) studied 59 E. coli strains that carried eae but lacked the EAF plasmid probe sequence and the stx genes, and found that $25.9 \%$ of the strains were FAS-negative. It is possible that eae-positive, FAS-negative strains possess some deficiency in expression of the genes encoding the type-III secretion system proteins and/or the secreted LEE proteins. Two eae-positive, FAS-negative strains were unable to attach to HEp-2 cells. According to Cantey \& Moseley (1991), nonadherent, eae-positive strains can possess adhesins capable of recognizing the intestinal mucosal surface, but not the cultured cells used in laboratory assays, for adhesion.

Fourteen different serogroups were detected. Forty-seven per cent of the strains belonged to classical O-serogroups of EPEC (O26, O86, O111, O114, O119, O127 and O142). The most frequent serotype found in our study was O119: H6 $(14.7 \%)$. All strains of serotype O119: H6 presented the LA pattern, were FAS-positive and were isolated from children with diarrhoea. Eleven strains were non-O-typable, and two were non-H-typable.

Adu-Bobie et al. (1998) revealed the existence of four distinct intimin types: intimins $\alpha, \beta, \gamma$ and $\epsilon$. Oswald et al. (2000) typed the intimin of the serotype O86:H34 EPEC strain
ICC95 as type $\beta$, although Adu-Bobie et al. (1998) had previously classified this intimin as type $\delta$. Restriction analysis of the PCR product obtained from strain ICC95 with $\beta$-specific primers as described by Oswald et al. (2000) showed a digestion profile, termed $\beta 2$, that differed from the $\beta 1$ pattern shared by all other intimin $\beta$-positive strains. According to Oswald et al. (2000), these data confirm that there are differences between the eae DNA sequences of serogroup O86 EPEC and the other $\beta$-type strains, and indicate that the $\beta 2$ subtype corresponds to the $\delta$ type of Adu-Bobie et al. (1998). Oswald et al. (2000) also revealed the existence of a new intimin type, referred to as intimin $\epsilon$.

It is interesting to note that intimin $\beta$ was detected in seven strains in this work, four of which belong to serotype O119: H6 (a classical EPEC serotype), and all of which were isolated from children with diarrhoea. According to the literature, intimin $\beta$ is the most common subtype among human strains of E. coli, and it seems that it is also the most common in bovine E. coli (Aidar et al., 2000; Vieira et al., 2001). On the other hand, intimin $\epsilon$ was found in two strains of serotype O111:H38 and one of serotype ONT:H19, isolated from children without diarrhoea. Oswald et al. (2000) detected intimin $\epsilon$ in human and bovine EHEC strains of serogroups O8, O11, O45, O103, O121 and O165. To our knowledge, this is the first report of the occurrence of intimin $\epsilon$ in strains isolated from humans in Brazil and the first report of $e a e^{+}, s t x^{-}$strains in the literature. The majority of strains studied $(70.6 \%)$ produced an intimin that could not be typed.

Haemolysin expression on blood agar was observed for only five strains (four after $24 \mathrm{~h}$ incubation and one after $3 \mathrm{~h}$ ), all of which were isolated from cases of diarrhoea. The low frequency of haemolysin expression among the eae-positive strains did not support a major role in enteropathogenicity.

The results obtained in this study indicate that AEEC are a heterogeneous group of organisms. However, typical EPEC continue to be important pathogens associated with diarrhoea in Brazilian children. $\mathrm{EAF}^{-}, b f p^{-}, e a e^{+}$E. coli strains have the potential, as a new enteropathogenic group, to become an important cause of diarrhoea in children.

\section{ACKNOWLEDGEMENTS}

The authors thank Fundação Araucária (Paraná-Brazil) and CAPES for financial support.

\section{REFERENCES}

Adu-Bobie, J., Frankel, G., Bain, C., Goncalves, A. G., Trabulsi, L. R., Douce, G., Knutton, S. \& Dougan, G. (1998). Detection of intimins $\alpha, \beta$, $\gamma$ and $\delta$, four intimin derivatives expressed by attaching and effacing microbial pathogens. J Clin Microbiol 36, 662-668.

Agin, T. S. \& Wolf, M. K. (1997). Identification of a family of intimins common to Escherichia coli causing attaching-effacing lesions in rabbits, humans, and swine. Infect Immun 65, 320-326.

Aidar, L., Penteado, A. S., Trabulsi, L. R., Blanco, J. E., Blanco, M., 
Blanco, J. \& Pestana de Castro, A. F. (2000). Subtypes of intimin among non-toxigenic Escherichia coli from diarrheic calves in Brazil. Can J Vet Res 64, 15-20.

Baldini, M. M., Kaper, J. B., Levine, M. M., Candy, D. C. A. \& Moon, H. W. (1983). Plasmid-mediated adhesion in enteropathogenic Escherichia coli. J Pediatr Gastroenterol Nutr 2, 534-538.

Baudry, B., Savarino, S. J., Vial, P., Kaper, J. B. \& Levine, M. M. (1990). A sensitive and specific DNA probe to identify enteroaggregative Escherichia coli, a recently discovered diarrheal pathogen. J Infect Dis 161, 1249-1251.

Beebakhee, G., Louie, M., De Azavedo, J. \& Brunton, J. (1992). Cloning and nucleotide sequence of the eae gene homologue from enterohemorrhagic Escherichia coli serotype O157:H7. FEMS Microbiol Lett 91, 63-68.

Beutin, L. (1991). The different hemolysins of Escherichia coli. Med Microbiol Immunol 180, 167-182.

Beutin, L., Zimmermann, S. \& Gleier, K. (1998). Human infections with Shiga toxin-producing Escherichia coli other than serogroup O157 in Germany. Emerg Infect Dis 4, 635-639.

Cantey, J. R. \& Moseley, S. L. (1991). HeLa cell adherence, actin aggregation, and invasion by nonenteropathogenic Escherichia coli possessing the eae gene. Infect Immun 59, 3924-3929.

Cravioto, A., Gross, R. J., Scotland, S. M. \& Rowe, B. (1979). An adhesive factor found in strains of Escherichia coli belonging to the traditional infantile enteropathogenic serotypes. Curr Microbiol 3 , 95-99.

Edwards, P. R. \& Ewing, W. H. (1972). Identification of Enterobacteriaceae, 3rd edn. Minneapolis, MN: Burgess.

Franke, J., Franke, S., Schmidt, H., Schwarzkopf, A., Wieler, L. H., Baljer, G., Beutin, L. \& Karch, H. (1994). Nucleotide sequence analysis of enteropathogenic Escherichia coli (EPEC) adherence factor probe and development of PCR for rapid detection of EPEC harboring virulence plasmids. J Clin Microbiol 32, 2460-2463.

Frankel, G., Candy, D. C., Everest, P. \& Dougan, G. (1994). Characterization of the C-terminal domains of intimin-like proteins of enteropathogenic and enterohemorrhagic Escherichia coli, Citrobacter freundii, and Hafnia alvei. Infect Immun 62, 1835-1842.

Frankel, G., Candy, D. C. A., Fabiani, E., Adu-Bobie, J., Gil, S., Novakova, M., Phillips, A. D. \& Dougan, G. (1995). Molecular characterization of a carboxy-terminal eukaryotic-cell-binding domain of intimin from enteropathogenic Escherichia coli. Infect Immun 63, $4323-4328$

Giraldi, R., Guth, B. E. C. \& Trabulsi, L. R. (1990). Production of Shigalike toxin among Escherichia coli strains and other bacteria isolated from diarrhea in São Paulo, Brazil. J Clin Microbiol 28, 1460-1462.

Girón, J. A., Ho, A. S. Y. \& Schoolnik, G. K. (1991). An inducible bundleforming pilus of enteropathogenic Escherichia coli. Science 254, $710-713$.

Gomes, T. A. T., Rassi, V., MacDonald, K. L. \& 8 other authors (1991). Enteropathogens associated with acute diarrheal disease in urban infants in São Paulo, Brazil. J Infect Dis 164, 331-337.

Gunzberg, S. T., Tornieporth, N. G. \& Riley, L. W. (1995). Identification of enteropathogenic Escherichia coli by PCR-based detection of the bundle-forming pilus gene. J Clin Microbiol 33, 1375-1377.
Jerse, A. E., Yu, J., Tall, B. D. \& Kaper, J. B. (1990). A genetic locus of enteropathogenic Escherichia coli necessary for the production of attaching and effacing lesions on tissue culture cells. Proc Natl Acad Sci U S A 87, 7839-7843.

Kaper, J. B. (1996). Defining EPEC. Rev Microbiol 27 (Suppl. 1), $130-133$

Kenny, B., DeVinney, R., Stein, M., Reinscheid, D. J., Frey, E. A. \& Finlay, B. B. (1997). Enteropathogenic E. coli (EPEC) transfers its receptor for intimate adherence into mammalian cells. Cell 91, 511-520.

Knutton, S., Baldwin, T., Williams, P. H. \& McNeish, A. S. (1989). Actin accumulation at sites of bacterial adhesion to tissue culture cells: basis of a new diagnostic test for enteropathogenic and enterohemorrhagic Escherichia coli. Infect Immun 57, 1290-1298.

Lin, Z., Kurazono, H., Yamasaki, S. \& Takeda, Y. (1993). Detection of various variant verotoxin genes in Escherichia coli by polymerase chain reaction. Microbiol Immunol 37, 543-548.

Louie, M., de Azavedo, J. C., Handelsman, M. Y. C., Clark, C. G., Ally, B. Dytoc, M., Sherman, P. \& Brunton, J. (1993). Expression and characterization of the eaeA gene product of Escherichia coli serotype O157 : H7. Infect Immun 61, 4085-4092.

McDaniel, T. K., Jarvis, K. G., Donnenberg, M. S. \& Kaper, J. B. (1995). A genetic locus of enterocyte effacement conserved among diverse enterobacterial pathogens. Proc Natl Acad Sci USA 92, 1664-1668.

Nataro, J. P. \& Kaper, J. B. (1998). Diarrheagenic Escherichia coli. Clin Microbiol Rev 11, 142-201.

Oswald, E., Schmidt, H., Morabito, S., Karch, H., Marchès, O. \& Caprioli, A. (2000). Typing of intimin genes in human and animal enterohemorrhagic and enteropathogenic Escherichia coli: characterization of a new intimin variant. Infect Immun 68, 64-71.

Pelayo, J. S., Scaletsky, I. C. A., Pedroso, M. Z., Sperandio, V., Girón, J. A., Frankel, G. \& Trabulsi, L. R. (1999). Virulence properties of atypical EPEC strains. J Med Microbiol 48, 41-49.

Saridakis, H. O. (1994). Non production of Shiga-like toxins by Escherichia coli serogroup O26. Rev Microbiol 25, 154-155.

Scaletsky, I. C. A., Silva, M. L. M. \& Trabulsi, L. R. (1984). Distinctive patterns of adherence of enteropathogenic Escherichia coli to HeLa cells. Infect Immun 45, 534-536.

Scaletsky, I. C. A., Pelayo, J. S., Giraldi, R., Rodrigues, J., Pedroso, M. Z. \& Trabulsi, L. R. (1996). EPEC adherence to HEp-2 cells. Rev Microbiol 27 (Suppl. 1), 58-62.

Scaletsky, I. C. A., Pedroso, M. Z., Oliva, C. A. G., Carvalho, R. B., Morais, M. B. \& Fagundes-Neto, U. (1999). A localized adherence-like pattern as a second pattern of adherence of classic enteropathogenic Escherichia coli to HEp-2 cells that is associated with infantile diarrhea. Infect Immun 67, 3410-3415.

Vieira, M. A. M., Andrade, J. R. C., Trabulsi, L. R., Rosa, A. C., Dias, A. M. G., Ramos, S. R. T. S., Frankel, G. \& Gomes, T. A. T. (2001), Phenotypic and genotypic characteristics of Escherichia coli strains of non-enteropathogenic E. coli (EPEC) serogroups that carry eae and lack the EPEC adherence factor and Shiga toxin DNA probe sequences. $J$ Infect Dis 183, 762-772.

Yu, J. \& Kaper, J. B. (1992). Cloning and characterization of the eae gene of enterohaemorragic Escherichia coli O157:H7. Mol Microbiol 6, 411-417. 